\title{
Building the Social Work Workforce: Saving Lives and Families
}

\section{Katharine Briar-Lawson}

\begin{abstract}
This article depicts a journey over the decades to address some of the needs of children and families in the child welfare system. Recounting a few key milestones and challenges in the past 40 years, it is argued that workforce development is one key to improved outcomes for abused and neglected children and their families. Major events and several turning points are chronicled. Emerging workforce needs in aging are also cited as lessons learned from child welfare have implications for building a gero savvy social work workforce. Funding streams involving IV-E and Medicaid are discussed. It is argued that workforce development can be a life and death issue for some of these most vulnerable populations. Thus, the workforce development agenda must be at the forefront of the social work profession for the 21st century. Key funding streams are needed to foster investments in building and sustaining the social work workforce.
\end{abstract}

Keywords: Workforce, IV-E, Medicaid, child welfare, aging, social work, universityagency partnerships

This article chronicles efforts to advance the leadership role of social workers to address the challenges of the most vulnerable children and families as well as the aging. Change strategies have involved the promotion of university-agency partnerships, workforce development, funding streams for social work education and new service delivery models. While much of the focus of my journey is centered on vulnerable children and families, by extension, inclusionary social work needs to comprise all ages. Thus, efforts at adapting some of these strategies to gerontological social work are delineated as well.

I first briefly recount child welfare workforce challenges, crises, several firsthand accounts of developments in workforce agendas and historical markers. Efforts to promote service innovations related to vulnerable children and families are offered. Following this, a brief overview of implications for gerontological social work is presented with similar attention to both workforce funding and some innovations in service delivery. Lessons learned are offered as are action steps for future developments in the field, including educational and professional supports for social workers.

Workforce development is not often thought of as a key facet of social work practice, let alone one that would be seen as a life and death issue for those we serve. Yet when workforce issues are overlooked, horrific consequences can occur. Children may die of abuse and neglect because a caseworker did not detect or understand domestic violence and its effects on the caregivers who subsequently cannot protect their child. An elder may leave the hospital with 921 different pills and may be unprepared for self-care in the community. Absent a trained social worker, the consequences may be toxic if not life threatening.

Katherine Briar-Lawson, Ph.D., MSW, is Dean and Professor in the School of Social Welfare at the University at Albany, State University of New York, in Albany, NY.

Copyright (c) 2014 Advances in Social Work Vol. 15 No. 1 (Spring 2014), 21-33 
This paper attempts to make the case that more attention is needed to promote workforce development, the partnerships that help incubate professional development of social workers and the potential funding streams that can attract social workers to the field and to working with some of the highest need populations. My journey has been one that has addressed some of these challenges. At the outset it is important to note that no journey is without partners along the way who open doors and make change synergistically possible. As change collaborators and facilitators we are always working with and through others. It is to them, gratefully, that I dedicate this article.

\section{Child Welfare: Partnership Movement}

We begin with child welfare, a field of practice that has long been the province of social work. From its inception as a field of practice for social workers over a century ago, social workers have been at the forefront of innovations to address the needs of the most vulnerable children and families (Briar-Lawson, McCarthy, \& Dickinson, 2013). While opportunities have abounded for social workers to be leaders in child welfare, the very architecture of this field of practice has hinged on a well prepared and sustained social work workforce.

Historically, from the emergence of the Children's Bureau 100 years ago to the present, social work has been identified as the profession with the most stake and professional alignment with the most vulnerable children, namely those who are abused and neglected. As spearheads for and leaders in the development of the Children's Bureau in 1912, social workers have worked to advance numerous reforms and innovations (Dickinson \& Barth, 2013). These included Mother's Pensions to prevent the need for institutional care for children whose mothers worked. In more recent decades, social workers have led innovations in home based services to prevent out of home placements (Landsman, 2013). In many cases such as these, social workers have been at the forefront, shaping many advances in child welfare.

Yet, much of this capacity to build the field of practice in child welfare has been compromised by setbacks. One such impediment in progress, from my point of view, involved the declassification or deprofessionalization movement in public child welfare. This occurred in the late 1960s through the mid to late 1980s. From this setback, as the next section illustrates, the profession has tried to regain its foothold and, even more, to advance a reprofessionalization movement. Some might argue, in fact, that reprofessionalization also requires more integrated services such as those that once dominated public sector social services and public welfare services, prior to the separation of income from services (Berns, Briar-Lawson, \& Kim, 2013).

\section{From Integrated Social Services to Deprofessionalization of Public Child Welfare}

Public child welfare services in the 1960s relied on social workers in AFDC or income maintenance roles to provide an integrated array of services including foster care, and special need grants to high need families to prevent out of home placement for their children. I learned, first hand, that through my welfare work (or income maintenance) 
service role (as a social work intern) in the 1960s that I was able to provide "long term care" for chronically fragile families with children at risk of out of home placement. This was made possible by casework services that included the ability as a caseworker to award "special needs" grants (beyond the basic welfare grant) to address unique family support needs. With the demise of such integrated services (casework and income supports) in the late 1960s and early 1970s (due to the separation of income support and social services) a radical role change occurred (Piliavin \& Gross, 1977). Caseworkers, who had previously provided prevention as well as family preservation through income maintenance services, were either shifted over to newly emerging Child Protection Services (CPS) or Adult Protection Services (APS). My frontline work and that of others at the time made it possible for families to remain intact due to the supports, extra financial resources and ongoing casework services for mothers and children. The separation of income maintenance from services severed families from such family preservation supports. Instead of these long term family support roles that were possible in the former welfare caseworker model or public social services, emergent new roles in child welfare comprised predominately CPS. Foster care and adoption services, once part of welfare services, also moved over into the new public child welfare system. Meanwhile, instead of social workers being sought after and recruited for newly emerging investigatory roles in CPS, other kinds of hiring occurred. This meant that the roles and jobs that might have been held by social workers were now going to others, many of whom had no relevant human services preparation. Moreover, in many if not most civil service bureaucracies, social work was not recognized or prioritized as the preferred skill base for work with these CPS families. In fact, by the early 1990s and continuing on to this day, only a handful of states require social work as the degree for practice in public child welfare.

Not surprisingly as public child welfare deprofessionalized, this field of service encountered many tragedies. High profile cases, media attention to horrific child deaths led, in many cases, local and state child welfare leaders to seek out help from schools of social work. Such help included delivery of training to caseworkers needing some exposure to social work knowledge and skills. It seemed so paradoxical that instead of hiring social workers, in many cases, untrained and uncredentialed applicants with a BA degree would be hired, only to face skill, practice and service crises that then resulted in requests to schools of social work to train these workers with "on the job" supports.

Prior to this, one of the most popular and sought after jobs in social work at the time, at least as I recall from the late 1960s, was private adoption services. One might ask how is it possible that the child welfare field could have gone from being a destination for social workers, to a time in which to this day, since then, some $40+$ years later, some county agencies in child welfare may not have seen a trained social worker in decades. How is it possible that the most vulnerable and highest need children and their families might be served by someone whose credentials, in some cases, were no more than a high school diploma? Had hospital operating rooms been purged of physicians there would be an outcry. This deprofessionalization movement, on the heels of the separation of income maintenance from services, constituted two strikes against the most vulnerable children and families. This more silent and hidden crisis for our most vulnerable children and 
families needed to be exposed. Moreover, when a high profile child welfare crisis occurred, such as a brutal beating or death of a child from abuse and neglect, the caseworker was often misrepresented and mislabeled in the media as being a "social worker." Such public crises and tragedies compounded the recruitment and retention problems in public child welfare agencies. Thus not only did the crisis involve human and very public tragedies, workforce churning and turnover, but catapulted into the media and to the forefront of the public the denigration if not demonization of social work as a profession.

In the late 1950s it had been estimated that more than half of public sector social service workers were trained social workers (Coll, 1995). Now the rates were very low, with prevalence rates of not more than 20-30\% (see Ellett \& Leighninger, 2006) being the norm. Such purging of the ranks of social work not only created skill, practice and service gaps but also eradicated or eroded social work values and knowledge as system drivers and redesign tools to address and improve practices.

Such deprofessionalization processes may have been a cost-saving device for some agencies. Moreover, the bureaucratization of services with rule driven and prescribed approaches to serving these highest need children and families, while loathsome to some social workers, may have seemed to some bureaucrats an efficient alternative to the more discretionary, advocacy oriented and professionally informed casework practice of the past. In the absence of social workers, trained to assess and solve problems, an emergent practice model evolved involving case management. (Depending on the skill level of the worker, this model may encourage an under-emphasis on engagement and assessment while over emphasizing "handing off" to other service providers the responsibility for problem solving). Such case manager referrals might involve up to 14 service providers to whom the family was known. Thus the untrained caseworker may "hand off" families to other service providers to address their abuse and neglect, mental health, addiction, domestic violence, disabilities, health, parenting skills, housing, income, employment, education , criminal and juvenile justice, child care and related needs and issues.

\section{Crisis in CPS: Crisis in the Workforce}

Insufficient assessment and engagement skills, a by-product of some untrained workers, reached a turning point when crack cocaine epidemics hit impoverished communities in the late 1980s. Child abuse deaths abounded. There were rumors that some cities had a death a day. Recruited away from a faculty post to lead a state based child welfare agency in these times, I was able to see firsthand how the rising challenges of the highest need children and families eluded many of our schools of social work. Few schools at the time had a specialization in child welfare and even fewer prepared or encouraged graduates to enter public child welfare. Moreover, not all agreed in our profession that CPS services were the right or proper paradigm for the use of social work skills and talents, given the investigatory and often adversarial role of CPS workers (Pelton, 1991). At the time I wondered, too, why families needed to maim themselves and those they loved to get help that then was seen as potentially hurtful. This was because CPS was emerging as a stigmatized service, frightening to many families and communities, especially diverse families and communities. 
It is not surprising that vacancy rates of up to one third of the workforce in CPS were emerging in many states and counties across the country. CPS work units churned with turnover among caseworkers, in part because many had no preparation for human services work. Many were rightfully daunted by the unpredictability of the effects of drugs on their clients. Others experienced vicarious trauma. One child welfare administrator later recalled that when he was able to get caseloads down to the nationally recommended safety level of 15 families per worker, many of his caseworkers did not know what to do as problem solvers with their families as they had no social work preparation. It was then that he built a campaign to reprofessionalize the workforce with social workers being hired throughout his state public child welfare agency.

Absent a skill base capable of addressing and delivering services tailored to the multiple challenges faced by vulnerable families, such turnover was not only predictable but an endemic indicator of the need for a workforce development campaign. In effect, the crisis among abused and neglected children culminating in high rates of child fatalities became a workforce crisis.

\section{NASW Commission on Families Addresses the Child Welfare Workforce Crisis}

To address this crisis I was fortunate to be able to have NASW as a change vehicle and a foundation for institutional reform. In fact, I was able to leverage change in my role as a newly appointed Chair of the Commission on Families for NASW and to approach, with Joan Zlotnik, staffing the Commission, the Acting Associate Commissioner of the Children's Bureau. We made the case that there was a staffing crisis in child welfare, especially in CPS. Such findings had emerged at a national conference in Washington State, hosted by the American Humane Association. The panel, of which I was a part, had been assigned the task of addressing needed competencies for CPS. Yet each speaker representing a state or county system around the country spoke about the staff vacancy crisis in CPS. It seemed to me that the crisis was the opportunity to redouble the efforts of social work to become reinvolved and reinvested in public child welfare.

\section{University-agency IV-E Partnerships Emerge}

When Dr. Zlotnik and I approached the Children's Bureau, in the late 1980s, we had identified the staffing crisis as the problem and came with a solution. We had evidence that federal funds, supporting the training of child welfare workers, through Section IV-E of the Social Security Act, were being used in Illinois with Schools of Social Work to educate social workers for public child welfare. At the time, very little in the field was known about IV-E and the potential to support the preparation of the workforce for child welfare. The Children's Bureau response resulted in the funding of a national workshop at NASW on the workforce needs in child welfare. The NASW Commission on Families hosted this and other nationally significant meetings to advance a partnership agenda between Schools of Social Work, NASW and public child welfare agencies (BriarLawson, 2012) 
It seemed to me that the skills of social workers among the National Association of Public Child Welfare Administrators (NAPCWA) leaders were also untapped. As I served as a member of NAPCWA and its executive committee, it seemed imperative that these leaders in child welfare be mobilized to support and facilitate IV-E partnerships. It was a moving moment when I asked the NAPCWA executive committee how many of them were social workers. To the surprise of many, there was a sizable number. During declassification and deprofessionalizaton, the profession itself had been sidelined in its leadership of public social services, which seemingly included the suppression of our social work identities. Once our social work identities were transparent we could begin to further the discussion about partnerships with schools of social work.

Then I became the Principal Investigator on two national Children's Bureau grants to forge partnerships between state and county agencies and schools of social work. This partnership movement began as a substantive problem solving agenda given the crisis and child deaths that were headlines around the country. Presentations were made at the National Association of Deans and Directors (NADD) and then I was funded to convene two national conferences on partnerships. Two publications resulted from these conferences (Briar, Hanson, \& Harris, 1992; Hooper-Briar \& Lawson, 1996). Entities like CALSWEC, first funded by the FORD Foundation, emerged as a national model on addressing workforce needs in child welfare (and in subsequent years adding mental health, aging and related fields of service). What began as an exploratory meeting with a leader at the Children's Bureau to advance the ways in which IV-E could help solve the vacancy crisis and build the workforce, has since evolved into an ever deepening workforce development agenda in social work.

Over 130 schools and educational departments of social work across the country now draw down about $\$ 80$ million a year in IV-E funds in support of the preparation of social workers for public child welfare (CSWE, 2011). IV-E funds cover student stipends, tuition, faculty costs for teaching specialty public child welfare courses, competency progress charting, evaluation, and field instruction. It should also be noted that since the mid-1970s to the present the Children's Bureau has funded traineeship grants to schools of social work to prepare students for public child welfare and to develop effective curricula (Briar-Lawson, 2012). From a financial standpoint, IV-E funds are the predominant drivers of explicit workforce development for frontline staff in child welfare.

\section{Protecting IV-E and Deepening the Workforce Development Agenda}

At one time, when congressional threats to IV-E looked ominous, we were able to quickly underscore the effectiveness of IV-E funded partnerships with two journal publications (also books, Briar-Lawson \& Zlotnik, 2003a, 2003b). These culminated in a new journal that I was able to help co-found: Public Child Welfare. It seemed to me at the time that too many fine evaluation studies of IV-E and public child welfare were not being published and another journal was needed to advance the evidence base for practice, workforce and organizational development. Moreover, parallel GAO (2003) and Annie E. Casey Foundation (2003) related reports emerged arriving at conclusions about the need for recruitment and retention innovations in child welfare. These reports and 
studies helped to propel a new kind of grant program at the Children's Bureau. Furthering this work was the systematic review done by Dr. Zlotnik and colleagues with the Institute for the Advancement of Social Work Research on Recruitment and Retention (Zlotnik, DePanfilis, Daining, \& Lane, 2005).

By 2002 new five year retention and recruitment grants were awarded by the Children's Bureau. These became the foundation for even deeper capacity building in workforce development. By 2008, workforce issues became a more visible focus for the Children's Bureau culminating in the development of the National Child Welfare Workforce Institute (NCWWI), for which I serve as a co-PI. While just a dream in 1987 that workforce would become a national focus in child welfare, the Children's Bureau now has made workforce issues a major focus of its work. NCWWI provides 11 Traineeship grants to schools; Leadership Academies for directors of public and tribal child welfare and deans of social work, middle managers, and supervisors; knowledge development; developmental evaluation and state level saturation models of organizational redesign to build a work culture conducive to effective practice and workforce retention. This newly refunded \$21 million investment in NCWWI (over a five year period) sends a signal nationally and internationally that effective outcomes require a well-trained and sustained workforce. As the child welfare milestone graph depicts some of the major developments of the past several decades, much work lies ahead.

Thus, while there are counties in the country that still may not have a trained social worker in child welfare and where some workers may only have a high school degree, the move toward capacity building and investments in the organizational context for effective workforce supports is a major $21^{\text {st }}$ century milestone. This is essential since some social work graduates complain that they cannot use their skills or feel alienated in compliance driven and sometimes toxic bureaucratic systems. Moreover, while the field still has a mixed workforce of social workers and non-social workers, significant progress has been made on a renewed workforce development campaign. Personally and professionally, for this author, much of my career has been invested in seeing this workforce focus evolve as one of the overriding paradigms for child welfare reform.

Challenges that lie ahead include the ways in which workforce investments can be definitively linked to improved outcomes for child welfare families and children. While we know that length of stay and reunification are affected by turnover (Flower, McDonald, \& Sumski, 2005); and have some evidence that IV-E trained social workers make better prepared caseworkers than non-IV-E trained practitioners (Leung \& Willis, 2012), closing the research gaps remain another vista for activism for the $21^{\text {st }}$ century. Other challenges involve the goodness of fit between well trained social workers and work conditions that problematically prize case management over sound clinical practice by caseworkers. Work roles of child welfare caseworkers comprise some of the most challenging social work jobs known to our profession. Yet the work conditions and workplace supports for such challenges are often insufficient, and some might say that they feel violated by their work conditions, which are often exacerbated by rule driven bureaucracies. Ideally every child welfare worker would be a trained social worker. At this time it is estimated that up to $40 \%$ of the workforce in public child welfare involves trained social workers (Dolan, Casanueva, Smith, \& Ringeisen, 2012). Thus, progress has 
been made with this workforce development journey through IV-E stipends and funding as well as Children's Bureau Traineeships.

Training administrators, middle and supervisory managers to be change leaders, a goal of NCWWI, will help build some of the necessary or preliminary conditions for organizational redesign. NCWWI change projects also involve the use of design teams, relying on the talents of frontline and supervisory staff and others to build change from the ground up. This may help with retention of staff and re-culturing of the workplace.

\section{Workforce Issues: Lessons Learned and Adapted to Aging}

It may seem curious that an advocate for child welfare practice and careers would emerge as one of the champions and spokespersons for building gerontological social work. Yet one of the great challenges facing the profession is the need to advance excellence in workforce development across all ages. This "inclusive excellence" agenda requires a parallel focus on aging. Often marginalized, like child welfare, from such mainstream fields of practice in social work as mental health, or school social work, it has been essential that some of the lessons learned from the child welfare workforce development campaign be brought to a parallel gerontological social work capacity building effort.

The John A. Hartford Foundation has made this possible, advancing gerontological social work as a mission for schools of social work as well as promoting aging and intergenerationally focused research, education and university-community partnerships. In fact, the John A. Hartford Foundation has invested over \$70 million into social work to build a gero savvy workforce. Dismal baseline data show the need (Scharlach, DamronRodriguez, Robinson, \& Feldman, 2000). The vista for social work leadership in community based systems of care in aging, including wrap around services, is very bright. That said, like child welfare, it has been important to find a funding stream beyond the funds from the John A. Hartford Foundation.

To that end the John A. Foundation recruited me early on to bring some of the workforce development principles and passions involving child welfare to gerontological social work. While the foundation has given grants and now is working to build capacity through several national centers, the need for a federal funding stream like IV-E seems ever pressing if we are to expand social work educational opportunities and also close the workforce gap.

It also seems curious that over \$3 billion a year in Medicaid and Medicare funds go to medical schools for medical education. One would think that such funds could be also used for gerontological social work education. Despite a study of Medicaid funding to schools of social work and attempts to bring such funding into stipends for field work in gerontology, the growth of Medicaid investments in social work is small (Behrman et al., 2006). However, given the Affordable Care Act, it may be possible to re-initiate efforts to build such educational investments in social work education. Of all fields social work probably is the most aligned with Medicaid populations and thus is the most likely to be in line for investments that are related to improved outcomes for Medicaid populations. 
Thus, like IV-E, Medicaid remains an important workforce development funding stream, but currently relatively untapped.

\section{Comparing Opportunities for Gerontological Social Workers with Public Child Welfare Workers}

The Affordable Care Act focuses on medical and behavioral health care in the community for all ages and invites more creative use of peers, community health workers and related supports including those for family centered care teams. Thus the role for social workers as design leaders in these new community based systems of care will be enhanced. Even more, the opportunity for social work as a profession to be aligned with quality care, community based support tailored to one's personal home based needs, underscores the image of social work as a profession on the cutting edge of reform and new $21^{\text {st }}$ century designs for improved life quality.

There is a parallel need for social workers to redesign public child welfare organizations and, in some cases, systems of care. Both fields of practice (in aging and in child welfare) can learn reciprocally about the ways in which "wrap around," home based services are essential to more well supported individual and family well-being. Abuse and neglect dynamics are risk factors across the lifespan. Thus the preventive tools and resources that ensure support and preempt these risk factors are system and service design opportunities for social workers.

Just as laws such as PL 96-272 moved us away from an over reliance on out of home placement and into more family preservation oriented practices so too will the Affordable Care Act and Medicaid redesign models ensure more community based systems of care and supports. Social workers may develop and implement more tailored care systems to lead, organize and build evidence-based family supports with psycho-educational and related interventions.

Social work as a profession depends on workforce supports from IV-E, traineeships and related NCWWI supports, and on John A. Hartford Foundation investments. Such supports for our workforce help to build innovations replacing unhelpful systems and services with more tailored, accountable and family centered strategies.

\section{Social Work: The Architect and Architecture for Systems Redesigns}

The profession of social work cannot be a design leader for new 21st century systems unless the profession has workforce development leadership and supports as its backbone for these newly designed programs and services. Thus improved outcomes for the most vulnerable require both the leadership of the profession around new service models as well as workforces comprised of trained social workers to make innovative practice possible.

The work that lies ahead includes more systematic summits and national work plans for developing the workforce. The Social Work Reinvestment Act, still pending before Congress, ignites such a planful approach and offers one such blueprint for our profession's future. At the state and local level, advocacy must occur on behalf of social 
workers whose debts are high for their schooling and who need investments in their education. This is especially pressing for students who come from diverse communities and who will return to serve them. In sum, workforce efforts need to increase for the profession and the highest-needs communities we serve to ensure a more effective future for all.

\section{References}

The Annie E. Casey Foundation. (2003). The unsolved challenge of system reform: The condition of the frontline human services workforce. Retrieved from http://www.aecf.org/upload/publicationfiles/the\%20unsolved\%20challenge.pdf

Baskind, F., \& Briar-Lawson, K. (2005). Advancing social work with older adults. Families in Society (Special Issue), 86(3), 424-430.

Behrman, G., Rizzo, V. M., Mancini, M., Briar-Lawson, K., Baskind, F., \& Valentine, C. (2006). Exploring strategies to advance public-sector funding in geriatric social work education. Journal of Social Work Education, 42(1), 37-48.

Berns, D., Briar-Lawson, K., \& Kim, W. H. (2013). Addressing poverty as a child welfare strategy. In K. Briar-Lawson, M. McCarthy, \& N. Dickinson (Eds.), The Children's Bureau: Shaping a century of practice, programs and policies (pp. 4358). Washington, DC: NASW Press.

Briar-Lawson, K. (2012). From a staffing crisis to the building of a national workforce agenda for social work. In E. F. Hoffler \& E. J. Clarke (Eds.), Social work matters: The power of linking policy and practice (pp. 53-58). Washington, DC: NASW Press.

Briar-Lawson, K., McCarthy, M., \& Dickinson, N. (2013). The Children's Bureau: Shaping a century of child welfare practices, programs and policies. Washington, DC: NASW Press

Briar-Lawson, K., \& Zlotnik, J. L. (Eds.). (2003a). Charting the impacts of universitychild welfare collaboration. New York, NY: Haworth Press.

Briar-Lawson, K., \& Zlotnik, J. L. (Eds.). (2003b). Evaluation research in child welfare. New York, NY: Haworth Press.

Briar, K., Hanson, V., \& Harris, N. (1992). New partnerships. Miami, FL: Institute on Children and Families at Risk, Florida International University.

Coll, B. (1995). Safety net and Social Security, 1929-1979. New Brunswick, NJ: Rutgers University Press.

Council on Social Work Education. (2011). 2010 Statistics on social work education in the United States: A summary. Retrieved from http://www.cswe.org/File.aspx?id=52269.

Dickinson, N., \& Barth, R. (2013). Lessons learned and the way forward. In K. BriarLawson, M. McCarthy, \& N. Dickinson (Eds.), The Children's Bureau: Shaping a 
century of child welfare practices, programs and policies (pp. 1-20). Washington, DC: NASW Press.

Dolan, M., Casanueva, C., Smith, K., \& Ringeisen, H. (2012). NSCAW II wave 2 report: Child and families receiving child welfare services post-baseline. OPRE Report \#2013-08. Washington, DC: Office of Planning, Research and Evaluation, Administration for Children and Families, U.S. Department of Health and Human Services.

Ellett, A. J., \& Leighninger, L. (2006). What happened? An historical analysis of the deprofessionalization of child welfare with implications for policy and practice. Journal of Public Child Welfare, 1(1), 3-34.

Flower, C., McDonald, J., \& Sumski, M. (2005). Review of turnover in Milwaukee County private agency child welfare ongoing case management staff. Unpublished monograph.

General Accounting Office. (2003). Child welfare: HHS could play an even greater role in helping child welfare agencies recruit and retain staff. (GAO-03-357). Washington, DC: Retrieved from http://www.gao.gov/new.items/d03357.pdf.

Hooper-Briar, K., \& Lawson, H. (Eds.). (1996). Expanding partnerships for vulnerable children, youth and families. Washington, DC: Council on Social Work Education.

Landsman, M. J. (2013). Family centered practice. In K. Briar-Lawson, M. McCarthy, \& N. Dickinson (Eds.), The Children's Bureau: Shaping a century of child welfare practices, programs and policies (pp. 59-78). Washington, DC: NASW Press.

Leung, P., \& Willis, N. (2012). The impact of Title IV-E training on case outcomes for children serviced by CPS. Journal of Family Strengths, 12(1), Article 9, 1-16. Retrieved from http://digitalcommons.library.tmc.edu/jfs/vol12/iss1/9/

Pelton, L. H. (1991). Beyond permanency planning: Restructuring the public child welfare system. Social Work, 36(4), 337-343.

Piliavin, I., \& Gross, A. E. (1977). The effects of separation of services and income maintenance on AFDC recipients. Social Service Review, 51, 389-406.

Scharlach, A., Damron-Rodriguez, J., Robinson, B., \& Feldman, R. (2000). Educating social workers for an aging society: A vision for the 21st century. Journal of Social Work Education, 36(3), 521-538.

Zlotnik, J. L. (2013). University-agency partnerships to advance child welfare. In K. Briar-Lawson, M. McCarthy, \& N. Dickinson (Eds.), The Children's Bureau: Shaping a century of child welfare practices, programs and policies (pp. 275-292). Washington, DC: NASW Press.

Zlotnik, J. L., DePanfilis, D., Daining, C., \& Lane, M. M. (2005). Factors influencing retention of child welfare staff: A systematic review of research. Institute for the Advancement of Social Work Research. Washington, DC: NASW Press. 


\section{Author note}

Address correspondence to: Katharine Briar-Lawson, Ph.D., Dean and Professor, School of Social Welfare, University at Albany, State University of New York, 1400

Washington Avenue, Albany, NY 12222. Email: kbriarlawson@albany.edu

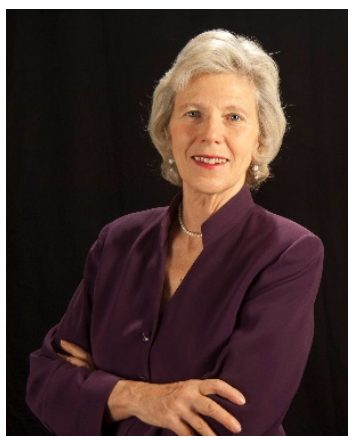

Katharine Briar-Lawson is Dean and Professor in the School of Social Welfare, University at Albany, State University of New York. She is a Co-PI of the National Child Welfare Workforce Institute. Among her books (co-authored) are Family-Centered Policies \& Practices: International Implications (2001), and (co-edited) Innovative Practices with Vulnerable Children and Families (2001), Evaluation Research in Child Welfare (2003), Charting the Impacts of University-Child Welfare Collaboration (2003), Social Work Research (2010), Social Work Practice Research (2010), Globalization, Social Justice and the Helping Professions (2011) and The Children's Bureau: Shaping a Century of Child Welfare Practices, Programs, and Policies (2013). She co-chairs the Gerontological Task Force for the National Association of Deans and Directors of Schools of Social Work and has served as a past president. 


\title{
Appendix A
}

\section{Child Welfare Workforce Agenda: Selected Milestones}

\author{
Mid - late 1980s \\ National workforce crisis in child welfare \\ $1987-1990$ \\ $\downarrow \quad$ NASW Commission on Families addresses workforce crisis \\ 1988 \\ K. Briar-Lawson \& J. Zlotnik approach and apprise Children's Bureau of \\ IV-E solution \\ $1988-1990$ \\ 1990 \\ $1990-1998$ \\ 2000-2005 \\ $2001-2003$ \\ $2002-2003$ \\ $2002-2014$ \\ NASW fosters workshops and publications on child welfare workforce \\ and university-agency solutions; beginning calls for police to replace \\ caseworkers in CPS \\ Children's Bureau promotes IV-E as a partnership and workforce \\ development resource with schools of social work/child welfare agencies \\ Children's Bureau funds two national conferences on IV-E partnerships; \\ two books published on partnerships \\ Institute for the Advancement of Social Work Research with the \\ $\downarrow$ Children's Bureau facilitate series of national meetings to address \\ workforce
2003
2005

